\title{
Stan języka ukraińskiego po odzyskaniu przez Ukrainę niepodległości w sierpniu 1991 roku
}

\author{
Bożena Zinkiewicz-Tomanek \\ Uniwersytet Jagielloński w Krakowie \\ bozena_zinktomanek@poczta.onet pl
}

\begin{abstract}
Streszczenie
$W$ artykule przedstawiono zmiany $w$ języku ukraińskim po odzyskaniu przez Ukraine niepodległości. Przed 1991 rokiem władza radziecka - prócz znanych z czasów Rosji carskiej różnego rodzaju zakazów - stworzyła system ingerencji w wewnętrzne prawa językowe, zabraniajac jednych wyrazów, konstrukcji syntaktycznych czy zasad ortograficznych, a propagując inne, bliższe językowi rosyjskiemu, który de facto posiadat pozycje dominujaca $w$ każdej prawie dziedzinie. Doprowadzito to do nienormalnej sytuacji językowej, nieświadomego mieszania języka ukraińskiego i rosyjskiego, do „rozchwiania” norm języka ukraińskiego zarówno fonetycznych, jak i morfologicznych, a także norm syntaktycznych oraz taczliwości leksykalnej. Dlatego też po 1991 roku - prócz zmian w systemie leksykalnym, zwiqzanych z rozwojem nauki, techniki oraz przekształceniami politycznymi i ekonomicznymi obserwujemy dażenie do odejścia od form zrusyfikowanych, naruszajacych normy ukraińskiego języka literackiego i powrót do starych rodzimych tradycji językowych.
\end{abstract}

Slowa kluczowe: polityka językowa, język urzędowy, język oficjalny, normy języka ukraińskiego, aktualizacja form rodzimych

Abstract

The State of Ukrainian after the Regaining of Independence by Ukraine in August 1991

The article discusses changes in Ukrainian after Ukraine had regained independence. Prior to 1991, the Soviet authorities - apart from various prohibitions known from the time of Russian tsars - had created a system of interfering in internal laws of language, prohibiting certain words, syntactic constructions or orthographic rules, and propagating others, closer to Russian, which had a virtually dominating position in nearly all fields. This led to an abnormal linguistic situation, the unconscious fusing of Ukrainian and Russian, both at the level of phonetics and morphology as well as syntactic norms and collocations. That is why, after 1991 - apart from changes in the lexical system, associated with developments in science, technology and political and economic transformations - we can observe the 
tendency to depart from Russified forms, which violate the norms of Ukrainian literary language, and to return to old native linguistic traditions.

Keywords: language politics, official language, standard language, norms of Ukrainian, updating of native forms

\section{Wstęp}

$\mathrm{Na}$ progu trzeciego tysiąclecia Ukraina, piękny i bogaty, lecz bardzo zrujnowany w sensie ekonomicznym i moralnym ponad 50-ciomilionowy kraj znalazł się w roku 1991 i znajduje się dziś w sytuacji porównywalnej z sytuacją Polski w roku 1918. Tak na ogół twierdzą historycy. Dodać jednak należy szereg problemów, których Polska wówczas nie miała: nikt bowiem w Polsce po 1918 roku nie zajmował się dyskusją nad wyborem języka urzędowego, było jasne, że odrodzona Polska to polski herb, polski hymn i ogólnopolski język jako jedyny język urzędowy.

Język ukraiński, jeden z trzech języków wschodniosłowiańskich, oficjalnie zgodnie $\mathrm{z}$ Ustawą o języku z roku 1989 oraz z art. 10 Konstytucji Ukrainy (przyjętej 28 czerwca 1996 roku) posiada na Ukrainie status języka urzędowego. Używany jest także w Rosji, gdzie mieszka ponad 4 miliony Ukraińców oraz w innych krajach byłego Związku Radzieckiego, a także w Polsce, Słowacji, Kanadzie, USA, Brazylii, Argentynie. Na Ukrainie mieszka ponad 37 min. Ukraińców (Ludy i języki. 2000:211).

Przed 1991 rokiem, gdy Ukraina wchodziła w skład Związku Radzieckiego, językiem oficjalnym był język rosyjski teoretycznie na równi z językiem ukraińskim, lecz de facto posiadał pozycję dominującą. Język ukraiński, jeśli nawet nie był oficjalnie dyskryminowany, zajmował pozycję drugorzędną, gorszą w każdej prawie dziedzinie.

Dla lepszego zrozumienia sytuacji językowej przypomnijmy, że wielokrotnie na Ukrainie (na ziemiach ukraińskich wchodzących w skład Rosji) zakazywano używania języka ukraińskiego. Za Piotra I (1720) wydany został zakaz drukowania książek po ukraińsku, zaś w 1753 roku Katarzyna II zabroniła prowadzenia w Akademii Kijowsko-Mohylańskiej wykładów w języku ukraińskim. Szczególnie znane są dwa dekrety. Pierwszy z nich to tzw. Wałujewski ukaz, sporządzony w roku 1863 przez ministra spraw wewnętrznych Piotra Wałujewa, który twierdził, że "nie było żadnego odrębnego języka małorosyjskiego, nie ma i być nie może". 
Dekret ten zabraniał drukowania książek po ukraińsku oraz zakazywał działalności teatru ukraińskiego, przy czym zakaz wystawiania sztuk w języku ukraińskim uchylono dopiero w roku 1881 (Serczyk, 1990: 268). Drugi - tzw. Emski ukaz Aleksandra II (podpisany przez cara w niemieckim uzdrowisku Ems) zabraniał wwożenia z zagranicy książek w języku ukraińskim oraz nawet drukowania nut po ukraińsku. W 1888 roku car Aleksander III zakazał używania języka ukraińskiego w urzędach oraz nadawania ukraińskich imion na chrzcie.

Na Ukrainie Radzieckiej, z jednej strony, decyzją władz partyjnych z 1938, nauczanie języka rosyjskiego - podobnie jak i we wszystkich republikach radzieckich - było obowiązkowe, z drugiej zaś, nauczanie drugiego języka (czyli języka danej republiki) było fakultatywne. Na dodatek na wszystkich uczelniach dominował jeżyk rosyjski, a w roku 1970 wydano zarządzenie nakazujące prowadzenia obron prac doktorskich i habilitacyjnych wyłącznie w języku rosyjskim. Dodajmy, że w 1983 roku zintensyfikowano nauczanie języka rosyjskiego w szkołach, a nauczycieli języka rosyjskiego wyróżniono swoistą nagrodą przyznano im 15\%-wy dodatek do pensji.

Poczynając od lat 30-ych pod hasłem internacjonalizmu oraz walki z tzw. burżuazyjnym nacjonalizmem zwalczano język ukraiński, usuwano go stopniowo ze szkoły, uczelni, a nawet przedszkola. Znany reżyser i pisarz ukraiński Ołeksandr Dowżenko w listopadzie 1956 r. pisze W swoim dzienniku: „W czterdziestym roku budownictwa socjalistycznego w stolicy czterdziestomilionowej Ukraińskiej Republiki Radzieckiej nauczanie /.../ prowadzone jest całkowicie w języku rosyjskim. Czegoś podobnego nie ma nigdzie na świecie. /.../. Co za niesłychana amoralność... Jakie okrutne oszustwo... I przykro, i wstyd..." (Dowżenko 1995: $542)$.

Język ukraiński stopniowo z biegiem lat przestał funkcjonować w różnych sferach życia społeczeństwa ukraińskiego, w urzędach, w wojsku, w nauce, w kulturze. Polityka władz doprowadziła do tego, że w Kijowie czy Zaporożu osoba rozmawiająca po ukraińsku traktowana była albo jak nacjonalista, albo jak człowiek drugiej kategorii. Nestor światowej ukrainistyki, wybitny językoznawca i historyk literatury Jurij Szewelow zwrócił uwagę na fakt, iż władza radziecka - prócz znanego z czasów Rosji carskiej zewnętrznego ucisku, różnego rodzaju zakazów - stworzyła system kontroli nad strukturą języka ukraińskiego i ingerencji w wewnętrzne prawa językowe. Władza ,zabrania jedne wyrazy, konstrukcje syntaktyczne, formy gramatyczne, ortograficzne i ortoepiczne zasady, a natomiast propaguje inne, bliższe do rosyjskich lub żywcem przeniesione z języka rosyjskiego" (Szewelow 1987: 263-264). Oczywiście sytuacja ta doprowadziła do „rozchwiania” norm języka ukraińskiego, czego skutki obserwujemy dziś w języku zarówno literatury pięknej, jak i środków masowego przekazu. Nie 
mówiąc już o tym, iż w Kijowie w urzędach, na uczelni, na poczcie możemy nie usłyszeć języka ukraińskiego, a w księgarni jest kilkakrotnie więcej książek w języku rosyjskim niż w ukraińskim. Co gorsza, niektórzy członkowie parlamentu - deputowani do Rady Najwyższej Ukrainy nawet nie starają się mówić po ukraińsku, wszelkie uwagi krytyczne traktując jako dyskryminację języka rosyjskiego.

Całe dziesięciolecia polityki językowej państwa doprowadziły do nienormalnej sytuacji. W Polsce, podobnie jak i w innych krajach europejskich w wyniku procesu demokratyzacji kultury znajomość literackiej polszczyzny stanowiła (i zresztą stanowi) czynnik decydujący o awansie kulturalnym określonych środowisk, natomiast na radzieckiej Ukrainie taki awans dawała znajomość języka rosyjskiego. I jeśli w przypadku języka polskiego mówiąc o swoistym bilingwizmie Polaków mamy na myśli używanie przez Polaków dwóch kodów - gwary i języka ogólnego, a w przypadku języka rosyjskiego od lat siedemdziesiątych mówi się o dwóch kodach - języku potocznym i języku literackim (por. m. in. prace prof. Jeleny Ziemskiej), to bilingwizm wielu Ukraińców polegał na używaniu w sytuacjach oficjalnych, w szkole, na uczelni itp. języka rosyjskiego, a na co dzień języka ukraińskiego lub, co gorsze, tzw. surżyku - swoistej mieszaniny języka ukraińskiego i rosyjskiego na każdym poziomie stratyfikacji językowej - i w zakresie fonetyki i morfologii, a może przede wszystkim leksyki i składni. Mam tu na myśli nie celowe wplatanie wyrazów rosyjskich przez osoby dobrze władające językiem ukraińskim „co wynikało z potrzeby zapełnienia pustki na miejscu ukraińskiego miejskiego slangu”. (Szewelow 1987: 263), lecz nieświadome mieszanie obu systemów językowych, ze szkodą zresztą zarówno dla języka ukraińskiego, jak i rosyjskiego.

\section{Zjawiska językowe}

Przejdźmy zatem do samych zjawisk językowych.

\subsection{Leksyka}

Na szczególną uwagę zasługują przypadki zmian w systemie leksykalnym, np. wejście licznych wyrazów - zapożyczeń (w szczególności w dziedzinie ekonomiki, techniki komputerowej itp.) oraz uaktywnienie się pewnych grup semantycznych, np. z zakresu religii i ogólniej z zakresu terminologii konfesyjnej (Styszow 1999: 15). Większość zapożyczeń to anglicyzmy bądź amerykanizmy, a więc nie tylko комп'ютер, lecz także oфic, принтер, файл, дизайн. Z drugiej 
strony, pośpiech i tendencja do skrótowości przyczyniły się do wzrostu liczby bardzo rozpowszechnionych w języku ukraińskim skrótowców, np. ЗМI (засоби масової інформаціï), ВАСУ (Вищий арбітражний суд), іномарка (автомобільіноземної марки), наркобизнес (нарокотиковий бизнес). Często używane skrótowce wchodzą do systemu słowotwórczego jako podstawy nowych wyrazów, np.СБ (Служба безпеки) - есбіст, НАТО - натівець.

System leksykalny jako najbardziej otwarty ze wszystkich podsystemów językowych w znacznym stopniu poddany był rusyfikacji, zresztą najłatwiej tej rusyfikacji się poddawał. W przypadku synonimów pewne wyrazy miały priorytet, inne zaś usuwane były na peryferie słownika przy pomocy kwalifikatorów „,przestarzały”, „gwarowy” itp. Np. preferowano spójnik щоб, ponieważ fonetycznie był bliższy do rosyjskiego чтобы, podczas gdy ukraiński spójnik аби odsuwany był na plan dalszy (Radzijewska 1999: 449-461).

Spora część zmian - oprócz normalnego rozwoju związanego z odmienną sytuacją społeczno-polityczną i ekonomiczną kraju - idzie więc w kierunku oczyszczenia języka z form będących wynikiem rusyfikacji oraz uaktywnienia form bardziej typowych dla języka ukraińskiego. Aktywizują się rodzime ukraińskie rzeczowniki, dotychczas odnotowywane w słownikach z kwalifikatorem „,przest.”, „rzadki”, ,gwarowy” bądź „regionalizm” i wypierane przez odpowiedni wariant maksymalnie zbliżony do rosyjskiego: фон - тло, поїзд - потяг, процент - відсоток, принцип - засада. Obserwujemy również aktywizację dewerbalnych rzeczowników na -ач, -ник typu завідувач, командувач, нападник zamiast завідуючий, командуючий, нападаючий, czyli wyrazów, które pojawiły się w języku ukraińskim pod wpływem odpowiednich rosyjskich formacji (заведующий, командующий, нападающий). Widoczne jest także aktywne wykorzystanie nazw osób ze względu na narodowość, miejsce zamieszkania itp. полтавець - полтавка, данець - данка, zamiast powszechnie używanych w czasach radzieckich formacji na -анин, -чанин, -анка, -чанка (nр. полтавчанин полтавчанка, датчанин - датчанка), со oznacza powrót do typowo ukraińskich w takich rzeczownikach sufiksów -ець, -ка.

\subsection{Fonetyka}

Jedną z dyskutowanych od 10 lat kwestii jest sprawa litery I. Z nakazu Stalina w 1933 r. litera ta zniknęła z alfabetu ukraińskiego, co miało na celu jeszcze większą unifikację obu bliskich języków w zakresie grafiki. Odtąd dwie różne spółgłoski zaczęto zapisywać jedną i tą samą literą. Trzeba było wiedzieć, w których wyrazach litera ta oznacza - rzadszą, co prawda spółgłoskę [g], a w których spółgłoskę [h]. Po 60-ciu latach okazało się, że użytkownicy języka 
zaczęli mylić te dwa dźwięki i w wielu wyrazach pod wpływem grafiki zamiast [g] zaczęto wymawiać [h]. Zmiany w alfabecie pociągnęły za sobą zmiany w systemie fonetycznym. Por. гава / гава $[\mathrm{g}]$ - город $[\mathrm{h}]$; гудзик / гудзик $[\mathrm{g}]$ - герой $[\mathrm{h}]$; гвалт / гвалт $[\mathrm{g}]$ - говорити $[\mathrm{h}]$; грунт / грунт [g] - громада [h]. Та ороzусja ma szczególne znaczenie w przypadku istnienia wyrazów różniących się fonemami [g] i [h]: гніт / гніт [g] 'knot' - гніт [h] 'ucisk'; грати / грати [g] 'kraty' - грати [h] 'grać'; гулі / гулі [g] 'gule' - гулі [h] 'zabawa, hulanie'. Wyrzucenie litery I nie tylko doprowadziło do mieszania spółgłosek [g] i [h], ale i do zaniku wymiany $[\mathrm{g}]-\left[\mathrm{z}^{\prime}\right]$ - [ž]. Por. дзига - кому? дзизі (ORF-1994) і дзидзі (SBur-1995). Lwowski uczony, prof. Ołeksandra Serbeńska uważa, że nazwisko Салига powinniśmy odmieniać - кому? Салидзі (nie zaś Сализi), a częsty w języku ukraińskim przymiotnik dzierżawczy od tego nazwiska powinien brzmieć Салиджин (Serbeńska 1994: 115).

W 1990 roku litera wróciła do alfabetu, jednakże dziś językoznawcy mają trudności z ustaleniem listy wyrazów, w których ta litera występuje. Osobny problem związany z tą literą stanowią zapożyczenia z języka angielskiego lub niemieckiego wyrazów typu hit, hot-dog lub nazw własnych Helmut, Hammer itp. Wbrew systemowi języka ukraińskiego wyrazy te zapisywane były według rosyjskich schematów: хіт, хот-дог, Хельмут, Хаммер, Хемінгуей, mimo iż ukraińskiej ortografii bliższy jest zapis гіт, гот-дог, Гельмут, Гаммер, Гемінгвей. Projekt ortografii (1999) zaproponowany przez prof. Wasyla Nimczuka przewiduje właśnie ten ostatni wariant. Podobnie zamiast dotychczasowego Гегель proponowany jest Гегель, zamiast Едвард Гріг - Едвард Гріг, zamiast Махатма Ганді - Магатма Ганді itd.

Do zjawisk fonetycznych należy opozycja [i : o] w wyrazach політ - польоту, переліт перельоту (por. ros. полёт - полёта, перелёт - перелёта). W wyrazach zawierających pierwiastek -літ- тоżna zauważyć preferowanie form zbliżonych maksymalnie do rosyjskich, podczas gdy starsze słowniki, np. słownik H. Hołoskewycza odnotowują raczej wariant z wymianą [i : e], nр. переліт - перелету (Hołoskewycz 1930/1994).

Interesujący jest los wyrazów, w których przez analogię do języka rosyjskiego kazano Ukraińcom pisać i wymawiać іуда, іудаїзм, ієрархія, діалект, діаспора oraz проект. Obecnie istnieje propozycja powrotu do bardziej ukraińskich zarówno od strony graficznej, jak i fonetycznej: юда, юдаїзм, єрархія, діялект, діяспора oraz проєкт.

Bardzo istotną sprawą jest wymowa niektórych dźwięków. Dotyczy to miękkiej wymowy spółgłoski [č], która w języku ukraińskim (podobnie jak w polskim) może być tylko twarda lub częściowo zmiękczona (por. początek - початок, czajnik - чайник, czerwony - червоний). Tylko przed samogłoską [i] lub w przypadku wzdłużenia spółgłoski [č] ulega ona częściowemu zmiękczeniu: очі, обличчя (zbliżone do polskiej wymowy nazwy Chile). Natomiast obecnie nie 
tylko na ulicy, ale również w radiu i w telewizji możemy usłyszeć wymowę, niepoprawną z punktu widzenia norm ortoepicznych języka ukraińskiego, np. [č’órnyej] zamiast [čórnyej]. Podobnie „nie-ukraiński” charakter mają wyrazy bez uproszczenia grupy spółgłoskowej, np. analogiczne do rosyjskiego brzmienie przymiotnika перемишльський zamiast typowego dla języka ukraińskiego перемиський. Na szczęście planowana reforma ukraińskiej ortografii ma te absurdy usunąć (Prawopys, Projekt 1999).

\subsection{Morfologia}

W odmianie rzeczowników r. męskiego niektóre formy przypadkowe „upodobniły się” do rosyjskich. Stąd w dopełniaczu 1. poj. w przeszłości zaczęła (podobnie jak w j. rosyjskim) przeważać końcówka -a, np. абзаца zamiast абзацу, коридора zamiast коридору.

W celowniku natomiast, gdzie j. ukraiński ma dwie równorzędne końcówki -овi i -y, zaczęto preferować końcówkę -y, wspólną dla obu języków. Dziś więc jesteśmy świadkami kształtowania się normy w zakresie fleksji rzeczownikowej z uaktywnieniem końcówki -y dopełniacza (автографу, баштану) oraz ze szczególnym uwzględnieniem typowej dla języka ukraińskiego końcówki celownika -ові (поетові, директорові, урядові, коневі).

Jednym z istotnych procesów we współczesnym języku ukraińskim jest aktywizacja form wołacza typowych dla języka ukraińskiego: Сергію! Іване! Докторе! Оксано! Читачу! Јęzyk rosyjski nie posiada formy wołacza, w funkcji tej używany jest mianownik: Сергей! Іван! Доктор! Оксана! Читатель!, nieprzypadkowo więc aż nazbyt często „zapominano” dotychczas o ukraińskiej formie wołacza.

\subsection{Lączliwość syntaktyczna i leksykalna}

Również w zakresie składni obserwujemy rozchwianie syntaktycznej normy pod wpływem składni rosyjskiej: зраджувати кому? zamiast зраджувати кого? (por. ros. изменять кому?); у найближчому часі zamiast найближчим часом (por. ros. в ближайшее время).

Liczne przykłady świadczą o nieprawidłowej leksykalnej łączliwości, a więc o niewłaściwym użyciu wyrazów w pewnych starych bądź luźnych połączeniach wyrazowych: приймати участь zamiast брати участь (por. ros. принимать участие); роздається голос zamiast розлягається, лунає голос (por. ros. раздаётся голос); строїтися в шеренгу zamiast шикуватися в шеренгу (por. ros. строиться в шеренгу); прикласти зусилля zamiast докласти зусиль (por. ros. приложить усилия); приносити шкоду zamiast завдавати шкоди (por. ros. приносить вред); приходить на думку, в голову zamiast спадає на думку (por. ros. 
приходит в голову); включати світло zamiast вмикати світло (por. ros. включать свет); рахувати, що ... zamiast вважати (гадати, думати, міркувати), що... (por. ros. считать, что...).

Warto zwrócić uwagę na jeszcze jeden istotny, jak się zdaje, fakt. Osoby, dla których język ukraiński jest językiem obcym, a więc studenci, wykładowcy, tłumacze z języka ukraińskiego stykają się z nie lada problemem podczas przekładania tekstu ukraińskiego przepełnionego rusycyzmami i elementami intertekstualnymi, zupełnie niezrozumiałymi bez znajomości języka rosyjskiego i rosyjskiej kultury, czy też szerzej - radzieckiej rzeczywistości. Por. np. stosunkowo proste zdanie: Громадянин країни, де „так вольно дишит человек”. W zdaniu tym kryje się pewna doza ironii, zrozumiała wyłącznie dla osób znających popularną przed laty radziecką pieśń „Широка страна моя родная”.

Jednym $\mathrm{z}$ istotnych obecnie problemów o charakterze międzynarodowym jest transkrypcja łacinką ukraińskich imion własnych - nazw geograficznych, nazwisk, imion itp. Zrozumiałe zastrzeżenia budzi zapis oddający rosyjskie brzmienie odpowiedniej nazwy. Zarówno bowiem u nas, jak i w innych państwach europejskich przyjęło się pisać: Kiev, Lvov, Siergiej zamiast Kyiv, Lviv, Serhij . Dlatego też nie powinno nas dziwić, że obecnie ukraińscy językoznawcy apelują, by nazwisko pisarza Ołesia Honczara pisać z literą H, a więc w angielskim wariancie: Honchar, a nie Gonchar. O zapis ukraińskich toponimów uwzględniający osobliwości języka ukraińskiego, a nie rosyjskiego upominał się jeszcze w 1977 r. kanadyjski uczony ukraińskiego pochodzenia Jar Slawutycz, który jako przedstawiciel Kanady brał udział w Międzynarodowej Konferencji ONZ poświęconej unormowaniu nazw geograficznych. (Sławutycz 1999: 63-69).

Należy dodać, że pierwsza próba wprowadzenia zmian w ortografii i w odmianie poszczególnych części mowy miała miejsce w 1990 roku, kiedy to w Instytucie Językoznawstwa im. A. Potebni Akademii Nauk (jeszcze USRR) uchwalono nową redakcję (tzw. 3-e wydanie, poprawione i uzupełnione) ortografii ukraińskiej (Prawopys 1990). Paradoks polega na tym, że te zasady ortografii oficjalnie podawane jako obowiązujące nigdy nie weszły do użytku powszechnego, a dyskusja nad ortografią trwa do dziś. Dość wspomnieć, że przez cały czas od 1990 roku do dziś w Kijowie wychodzą gazety i czasopisma stosujące co najmniej dwie różne zasady ortografii.

Jest swoistym paradoksem, że w tym samym czasie w Kijowie, w zasadzie w tej samej Akademii Nauk powstają słowniki ortograficzne, powołujące się na nową redakcję zasad ortografii, natomiast w rzeczywistości podające różne rekomendacje. W wyniku zestawienia dwu ortograficznych słowników - słownika z roku 1994 (Orf-94) oraz słownika A. Buriaczka z 1995 roku (SBur-1995) stwierdzono ponad 120 różnych rekomendacji z zakresu ortografii, 
morfologii i akcentuacji. Warto jednak przypomnieć, że dowolne prawo, w tym i zasady ortograficzne nie tyle muszą być logiczne, co konsekwentnie przestrzegane.

\section{Wnioski}

Zmiana ustroju państwa, zmiana totalitarnego systemu przyczyniła się do demokratyzacji języka, większej jego unifikacji. Szybki rozwój ukraińskiej prasy, intensywny rozwój radia i telewizji ukraińskiej - zarówno państwowej, jak i prywatnej - spowodował znaczne wzbogacenie słownictwa i bardziej ogólny jego zasięg, język dociera do wszystkich zakątków kraju. Jednakże brak sztywno ustalonej normy, a ściślej mówiąc rozchwianie norm językowych sprawia, że środki masowego przekazu z punktu widzenia kultury języka ukraińskiego niekoniecznie propagują poprawne formy językowe.

Z drugiej jednak strony, walka językoznawców o czystość języka ukraińskiego, wzrost liczby wydawnictw poświęconych poprawności językowej powoli dają widoczne rezultaty. Prócz zmian $\mathrm{w}$ systemie leksykalnym, związanych $\mathrm{z}$ rozwojem nauki, techniki oraz przekształceniami politycznymi i ekonomicznymi, obserwujemy odejście od form zrusyfikowanych, naruszających ukraiński kanon literacki „i powrót ku starym ukraińskim tradycjom językowym”. Jak pisze D. Wieczorek , te antyrusyfikacyjne procesy można traktować jako swoiste innowacje, innowacje á rebours" (Wieczorek 1999: 441).

\section{Źródło}

Tekst ten został po raz pierwszy opublikowany w 2000 roku w tomie Język trzeciego tysiaclecia pod redakcją Grzegorza Szpili, Język a komunikacja 1. Kraków: Tertium; 341-349.

\section{Bibliografia}

Чак, Свгенія (1997) Чи правильно ми говоримо. Київ: Освіта.

Довженко, Олександр (1995) Щоденник. Київ.

Damm, Krystyna, Aldona Mikusińska (red.), (2000) Ludy i języki świata. Leksykon PWN. Warszawa: PWN.

ORF-1994, Орфографічний словник украӥнської мови. Київ: Довіра.

Пономарів, Олександр (1999) Культура слова. Мовностилістичні поради. Київ: Либідь.

Radzijewska, T. (1999) „Процес текстотворення у білінгвістичній мовній ситуації (лінгвокультурологічний аспект)”. Slavia Orientalis, 3; 449-461. 
SBur-1995, Бурячок, Андрій, А. Орфографчний словник. Київ: Наукова думка.

Сербенська Олександра (red.) (1994) Антисуржик. Львів: Світ.

Serczyk, Władysław, A. (1990) Historia Ukrainy. Wrocław-Warszawa-Kraków: Zakład Narodowy im. Ossolińskich.

Славутич, Яр (1996) „У яких словах писати Г”. Мовознавство, 1; 63-69.

Styszow, О. (1999) „Особливості розвитку лексичного складу української мови кінця ХХ ст.". Мовознавство, 1; 7-21.

Шевельов, Юрій (1987) Украӥнська мова у першій половині двадиятого століття (19001941). Cтан i cmamyc. [The Ukrainiane language in the First Half of the 20th Century (1900-1941): State and Status. Nowy Jork: Сучасність] (tłum.) Оксана Соловей. Nowy Jork: Сучасність.

Wieczorek, Diana (1999) „Новационные процессы в современном украинском языке”. Slavia Orientalis, 3; 435-441. 